\title{
A focused, longitudinal analysis of cannabinoid hyperemesis syndrome symptomatology
}

\author{
Philip H. Ma ${ }^{1} \mathbb{D}$, Katherine M. Joyce ${ }^{2}$, Thayer Morton ${ }^{3}$, David W. Shih ${ }^{2,4}$, Alexander Weiss ${ }^{2}$ and Joseph Miller ${ }^{2 *}$
}

Keywords: Cannabinoid hyperemesis syndrome, Cyclic vomiting, Cannabis

To the Editor,

After reading the review article titled "The emergency department care of the cannabis and synthetic cannabinoid patient: a narrative review" by Kevin Takakuwa and Raquel Schears published in the International Journal of Emergency Medicine (2021 Feb 10;14(1):10), we want to first congratulate the authors for the successful publication of this article. Additionally, we hope to contribute some of our findings to further enhance this line of research.

\section{Introduction}

As the legalization of cannabis continues to spread in North America, it has become increasingly important for physicians to recognize and treat cannabinoid-related syndromes. In this secondary analysis of a randomized controlled trial that studied the effect of topical capsaicin on patients presenting to the emergency department (ED) with cannabinoid hyperemesis syndrome (CHS), we describe symptomatology and return visits in patients suffering from CHS [1].

\section{Results}

Our study population consisted of 29 participants with a mean age of 30 years. Most patients were Black (90\%) and hypertension was the most frequent comorbid condition (28\%). All participants experienced nausea and vomiting. Other reported symptoms included abdominal

\footnotetext{
* Correspondence: jmiller6@hfhs.org

${ }^{2}$ Henry Ford Hospital, Detroit, MI, USA

Full list of author information is available at the end of the article pain (90\%), chills (52\%), and diarrhea (27\%). Abdominal pain was mild (mean visual analog scale (VAS) $2.7 \pm 1.2$ $\mathrm{cm}$ ) compared to nausea (mean VAS $7.3 \pm 2.5 \mathrm{~cm}$ ). Sixteen patients accounted for 41 repeat ED visits and 10 hospitalizations for CHS-related symptoms within 6 months.

\section{Discussion}

Data indicates that the increased accessibility of cannabis in the USA is associated with an increase in cannabis-related conditions presenting to the ED [2]. Many of these conditions have only recently been characterized and a clearer understanding of $\mathrm{CHS}$ symptomatology may improve its accurate recognition and treatment.

While the majority of published studies of CHS obtain retrospective data or present small case series, this prospective data provides an accurate assessment of patient symptoms and high rates of return visits. It also includes data on a largely Black cohort, whereas most published literature on CHS is inclusive of White patients. We present quantified data on the degree of nausea common among CHS patients and the degree of abdominal pain. Contrary to prior studies, we found that abdominal pain severity is overall mild to moderate, especially when compared to nausea severity [3]. Given these findings, a focus on antiemetic treatment rather than analgesics appears warranted in the initial management of these patients. 


\section{Conclusions}

In this cohort of CHS patients, it was found that nausea was a larger concern for patients than abdominal pain and that repeat encounters for related symptoms were common. As cannabinoid use becomes more mainstream, physicians in all settings should include CHS in their differential when faced with GI symptoms.

\section{Abbreviations}

CHS: Cannabinoid hyperemesis syndrome; VAS: Visual analog scale;

CVS: Cyclic vomiting syndrome

\section{Acknowledgements}

We would like to thank the Department of Emergency Medicine at Henry Ford Hospital for supporting this research.

\section{Authors' contributions}

All authors were involved in writing and manuscript editing. JM and PM conceived the design. JM performed analysis. The authors read and approved the final manuscript.

\section{Funding}

This research did not receive any specific grant from funding agencies in the public, commercial, or not-for-profit sectors.

\section{Availability of data and materials}

Data is not publically available

\section{Declarations}

\section{Ethics approval and consent to participate}

The study was approved by the institutional review board and all participants provided written consent.

\section{Consent for publication}

Not applicable

\section{Competing interests}

The authors declare that they have no competing interests.

\section{Author details}

${ }^{1}$ Wayne State University School of Medicine, Detroit, MI, USA. ${ }^{2}$ Henry Ford Hospital, Detroit, MI, USA. ${ }^{3}$ Michigan State University College of Osteopathic Medicine, East Lansing, MI, USA. ${ }^{4}$ Schulich School of Medicine \& Dentistry, London, Ontario, Canada.

Received: 2 July 2021 Accepted: 10 July 2021

Published online: 29 July 2021

\section{References}

1. Dean DJ, Sabagha N, Rose K, Weiss A, France J, Asmar T, et al. A Pilot Trial of Topical Capsaicin Cream for Treatment of Cannabinoid Hyperemesis Syndrome. Acad Emerg Med. 2020;27(11):1166-72. https://doi.org/10.1111/a cem.14062.

2. Monte AA, Shelton SK, Mills E, Saben J, Hopkinson A, Sonn B, et al. Acute illness associated with cannabis use, by route of exposure: an observational study. Ann Intern Med. 2019 Apr 16;170(8):531-7. https://doi.org/10.7326/M1 8-2809

3. Simonetto DA, Oxentenko AS, Herman ML, Szostek JH. Cannabinoid hyperemesis: a case series of 98 patients. Mayo Clin Proc. 2012;87(2):114-9. https://doi.org/10.1016/.jmayocp.2011.10.005.

\section{Publisher's Note}

Springer Nature remains neutral with regard to jurisdictional claims in published maps and institutional affiliations.
Ready to submit your research? Choose BMC and benefit from:

- fast, convenient online submission

- thorough peer review by experienced researchers in your field

- rapid publication on acceptance

- support for research data, including large and complex data types

- gold Open Access which fosters wider collaboration and increased citations

- maximum visibility for your research: over $100 \mathrm{M}$ website views per year

At BMC, research is always in progress.

Learn more biomedcentral.com/submissions 